\title{
Biochemical analysis of Psophocarpus tetrgonolobus L. (Winged bean) and its role on restoration of degraded land of Raniganj and Barjora coalmine areas of West Bengal, India
}

\author{
Anjan Kumar Sinha \\ Department of Botany, Bankura Sammilani College, Bankura- 722102 (West Bengal), INDIA \\ Email: anjansinha06@gmail.com
}

Received: March 28, 2014; Revised received: December 06, 2014; Accepted: December 10, 2014

\begin{abstract}
To meet the growing demands of energy, continuous supply of coal is necessary because coal is the primary source of energy. About $70 \%$ of coal mining is being done by open cast methods which is most destructive activity and it severely damages the ecosystem. Reclamation of degraded land is therefore necessary after any mining activity. The biochemical parameters like Chlorophyll, carbohydrate and protein content of Psophocarpus tetragonolobus (Winged bean) studied here were considered as measure to test the suitability of Winged bean in various soil-OB dump compositions $\left(P_{1}\right.$ to $\left.P_{5}\right)$. The findings revealed that biochemical property like chlorophyll and protein content of Winged bean was retained up to $1: 1$ soil-OB dump condition but after that it was decreased significantly whenever OB dump composition was increased. Chlorophyll content of the plant in $\mathrm{P}_{1}$ to $\mathrm{P}_{3}$ condition was 8.2, 8.17 and 8.02 $\mathrm{mg} / 100 \mathrm{gm}$ respectively but it was decreased significantly in $\mathrm{P}_{3}$ and $\mathrm{P}_{4}$ condition, i.e. $7.72 \& 7.47 \mathrm{mg} / 100 \mathrm{gm}$ respectively. Carbohydrate content of the plant in $P_{1}$ to $P_{3}$ condition was $3.72,3.7$ and $3.61 \mathrm{gm} / 100 \mathrm{gm}$ respectively but it again decreased significantly in $\mathrm{P}_{3}$ and $\mathrm{P}_{4}$ condition, i.e. $3.32 \& 3.1 \mathrm{gm} / 100 \mathrm{gm}$ respectively. In spite of these findings, seeds of winged bean contained high protein and rest of the plant parts were also very important as food and fodder and this plant was able to grow on less water condition which made it suitable for the land restoration of degraded mining land both from ecological and socio-economic point of view.
\end{abstract}

Keywords: Barjora, Coal mine, Land reclamation, Psophocarpus tetragonolobus, Raniganj

\section{INTRODUCTION}

Psophocarpus tetragonolobus commonly known as Winged bean is a tropical crop plant mostly climbing, herbaceous and perennial. Winged been is not so common in West Bengal vegetables field but it is a very promising crop. Its leaves, flowers, pods, green seeds, dried seeds and tuberous roots are all edible and nutritious (Garcia and Palmar 1980). This plant is listed as one of the under-exploited legumes. Winged bean has wide ranges of use. Their 'milk' and flour are used as dietary treatment for protein-deprived children, young shoots and leaves of winged bean may be eaten raw or cooked as green vegetables. The flower can be eaten raw, fried or steamed, roasted tuber are also edible (Singh et al., 2013). Tuber of winged bean consist of very high amount of protein $(8-20 \%)$ as compared to the common cultivars of most root crops, flowers of winged bean also contain protein (Garcia and Palmar 1980; Singh et al., 2013). Amoo et al. (2006) has reported that crude protein content of winged bean was higher than the cowpeas seeds, pigeon pea, and lime bean. In winged bean, the protein content is $33.82 \%$ in comparison to the cowpea $(22.5 \%)$, pigeon pea $(22.4 \%)$ and the lime beans (23.3\%) (Aletor and Aladetimin,1989) and even comparable with the protein content of soya bean (35\%) (Adeyeye, 1995). Winged bean also contains edible oil (15-20\%), Vitamin A (300-900 IU), and also rich in carbohydrate (Singh et al., 2013). Carbohydrate content of winged bean was comparable with the value found in peas, jackfruit, yam, potatos and mangoes (Sumati and Rajagopal 1989; Amoo et al., 2006). As because winged bean nodulate heavily than the other legume plants, it fixes more $\mathrm{N}_{2}$ into the soil, $\mathrm{N}_{2}$ concentration of soil gradually increases and soil becomes fertile. The crop is very hardy and can be grown with minimal care and very little irrigation.

The winged bean plants have been tried for the reclamation programmes by various workers. Gupta et al. (2002) studied growth performance of winged bean on Coal mine region of Jharkhand and reported that winged bean is a potential crop of this region for reclamation of degraded land. Sinha (2012) for the first time, made an effort to introduce winged bean into the degraded soil of Raniganj coal mine of Bardhaman district and reported significant results. Sinha (2013) again tested the growth performance potentiality of winged bean in the mine spoil of Barjora coal field, a newly formed coal field of Bankura district of West Bengal and reported a positive results. He also 
reported significant results on growth performance of various morphological parameters of $P$. tetragonolobus (Winged bean) in various soil-Over Burden dump (OB dump) composition of Raniganj and Barjora coal mine. Usually during the mining activity lot of extraneous over burden materials are generated which are stored in nearby areas and over the years it acquires the shape of hillocks which are called as as over burden dump (OB dump) or mine refuse dumps (MRD) or mine spoil.

Dumping of mine spoil in coal field area is considered as a major contributor to the ecological and environmental degradation (Cherfas, 1992; Chaoji, 2002; Ghosh 2004; Deke Boruah et al. 2008). According to Chaoji, (2002) coal mining industry is being placed under the red category and it is one among the top of environmental degradation procedures. OB dumps are nutritionally poor, loosely adhered to particles of shale, stone, boulder and so forth and are devoid of true soil characters (Raju and Hassan 2003, Deka Boruah et al 2008, Gogoi et al.2007). Restoration of degraded land is a lengthy process and a minimum period of more than 50 years to a century is required to establish true vegetation coverage on degraded land (Dobson et al., 1997). There are many restoration processes implemented around the world (Cunnigham and Berti 1993; Mendez and Maier, 2008). Tiwary ( 2001), Wong, (2003), Pal ( 2003) Ghosh ( 2004) Gonzalez et al., (2006), Maiti ( 2007); Juwarkar and Jumbalkar ( 2008) have reported many successful restoration of degraded land in India, but to date, no attempt is being made to remediate mine OB dumps of Raniganj and Barjora coal mine of West Bengal by utilizing unexploited plant like winged bean ( $P$. tetragonolobus). This investigation sought to achieve eco-restoration of the degraded land of these coal mine region through the introduction of winged bean which is important ecologically as well as economically and emphasis was given to the involvement of local people of the coal mine areas to achieve overall goal of the ecological restoration programme.

The aim of the present study was to investigate fluctuation of various biochemical parameter (chlorophyll content, protein content, and carbohydrate content) of $P$. tetragonolobus (Winged bean) in various soil- OB dump combination and to provide valuable data so that the plant may be prescribed for reclamation programme.

\section{MATERIALS AND METHODS}

Sample collection: Seeds of winged bean $(P$. tetragonolobus) were obtained from National Bureau of Plant Genetic Resources (NBPGR), Pusa Campus, New Delhi-110 012. Mine spoil (OB dump) of different age were collected from various open cast coal mine area of Raniganj and Barjora coal belt of West Bengal, India.

Sample preparation: Pot culture experiments were set up and five sets of culture medium were made i.e. a) Control condition constituted $100 \%$ forest top soil without fertilizer $\left(\mathrm{P}_{1}\right)$ b) Second condition represented $75 \%$ forest top soil and $25 \%$ OB dump $\left(\mathrm{P}_{2}\right)$, c) Third condition constituted $50 \%$ forest top soil and $50 \%$ OB dump $\left(\mathrm{P}_{3}\right)$, d) $25 \%$ forest top soil and $75 \%$ OB dump $\left(\mathrm{P}_{4}\right)$ and e) This condition represented $100 \%$ OB dump or mine spoil $\left(\mathrm{P}_{5}\right) .100$ seeds were sown on each of the test culture to percentage germinations. Ten replicated of germinated seeds were sown on each of the test culture.

Biochemical analysis: Biochemical analysis like chlorophyll estimation (Arnon, 1949) and carbohydrate estimation by Anthrone method (Hodge and Hofreiter, 1962; Loewus, 1952) were determined. For protein estimation digestion and distillation method was followed for the analysis of total Nitrogen content and then percentage nitrogen was converted into protein content by multiplying with 6.25 as reported by Pearson (1976) because $1 \mathrm{mg}$ nitrogen equals to $6.25 \mathrm{mg}$ protein.

Data were collected in two consecutive years i.e. 2012 and 2013 in the growing period of the crops. Mean value of the data of the two consecutive years are to be taken for the data evolution.

\section{RESULTS AND DISCUSSION}

Results of the biochemical analysis of P. tetragonolobus (Winged bean) are given in Table 1 and Figs. 1 to 3 . Chlorophyll content of this plant grown on different soil-OB dump composition condition show an average range in between $8.2 \mathrm{gm} / 100 \mathrm{gm}$ to $7.47 \mathrm{gm} / 100 \mathrm{gm}$, respectively. The highest value was observed in $\mathrm{P}_{1}$ (100\% soil) condition and the lowest value was observed in $\mathrm{P}_{5}$ condition (100\% OB dump). Plants grown into the study plots $\mathrm{P}_{2}$ and $\mathrm{P}_{3}$ condition still maintain their chlorophyll content somehow constant. But in study plot $\mathrm{P}_{4}$ and $\mathrm{P}_{5}$ condition, it was observed that chlorophyll content of the plant had decreased (Fig.1).

Carbohydrate content of this plant grown on different soil-OB dump composition condition showed an average range in between $3.75 \mathrm{gm} / 100 \mathrm{gm}$ to 3.16 $\mathrm{gm} / 100 \mathrm{gm}$. The highest value was observed in $\mathrm{P}_{1}$ (100\% soil) condition and the lowest value was observed in $\mathrm{P}_{5}$ condition (100\% OB dump). It was also observed that carbohydrate content of plants of same study plot varied in two consecutive years. Highest variation of carbohydrate content in between two years was observed in $\mathrm{P}_{4}$ condition, it was $0.13 \mathrm{gm} / 100 \mathrm{gm}$. Lowest variation was observed in $\mathrm{P}_{2}$ condition $(75 \%$ soil and $25 \% \mathrm{OB}$ ) and it was $0.2 \mathrm{gm} / 100 \mathrm{gm}$. The results clearly indicate that plants can maintain their carbohydrate contain up to the $\mathrm{P}_{3}$ condition i. e. where plants are grown on 50\% soil and 50\% OB dump condition but after that carbohydrate content of the plants had decreased (Fig.2).

Protein content of the plant varied from $5.71 \mathrm{gm} / 100 \mathrm{gm}$ 


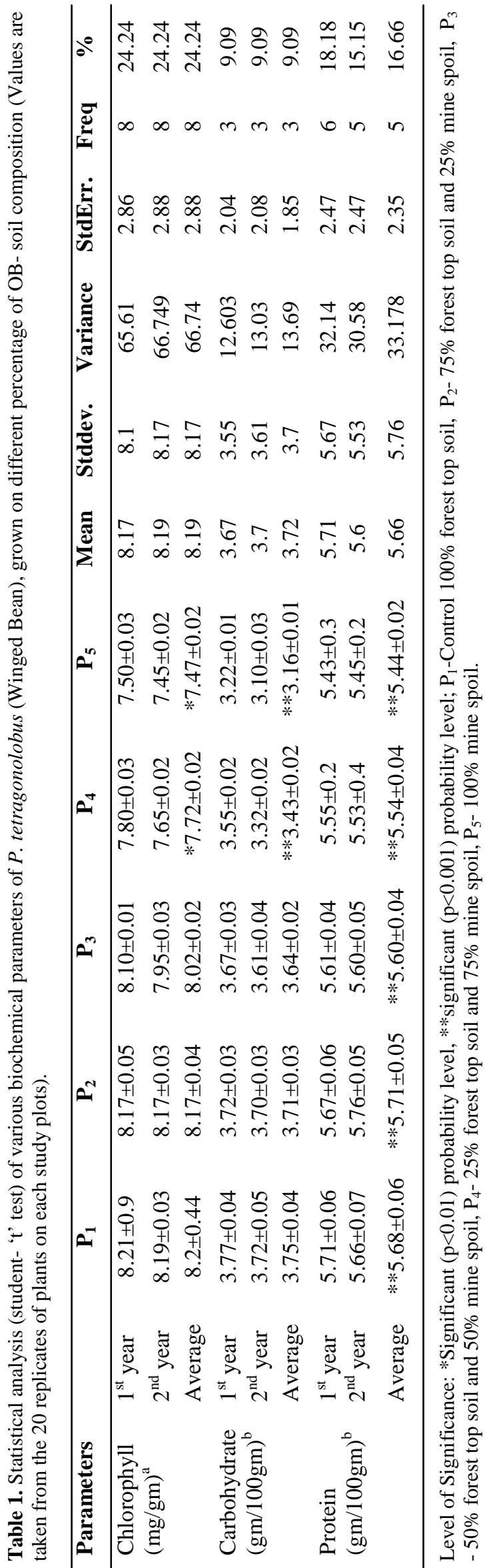

Chlorophyll (mg/gm)

1styr. $\quad$ 2nd Yr.

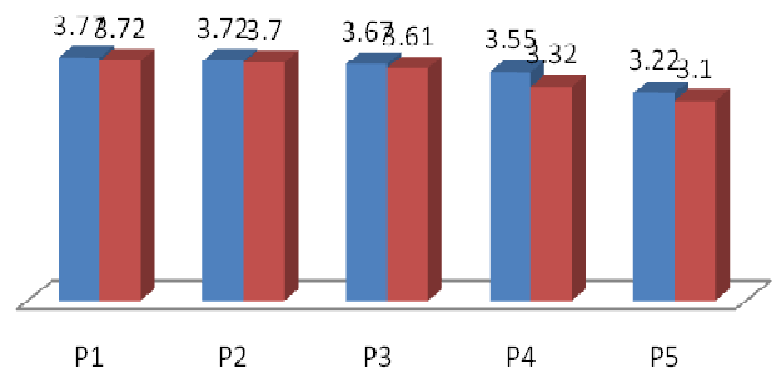

Fig. 1. Comparative chlorophyll content of winged bean among the various study plots.

\section{Carbohydrate (gm/100gm)}

$\square$ 1st yr. $\quad$ 2nd Yr.

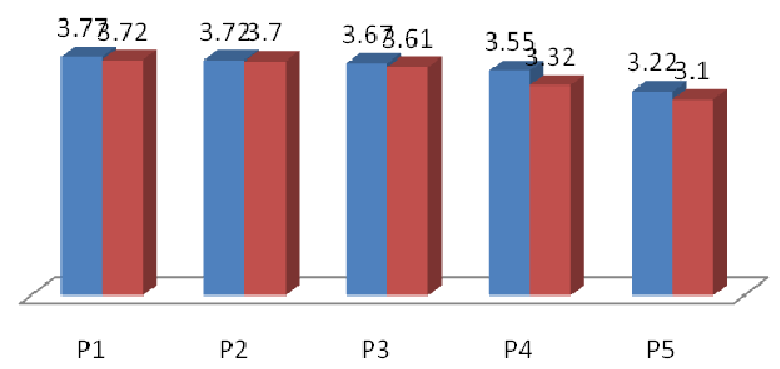

Fig. 2. Comparative carbohydrate content of winged bean among the various study plots.

\section{Protein (gm/100gm)}

1styr. $\quad$ 2nd Yr.

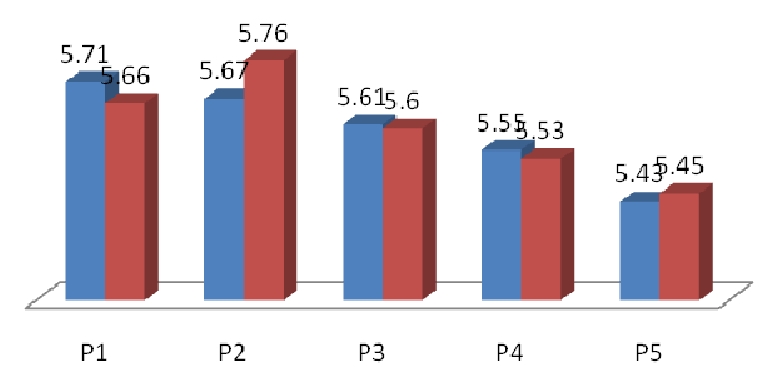

Fig. 3. Comparative protein content of winged bean among the various study plots.

to $5.44 \mathrm{gm} / 100 \mathrm{gm}$ in the $\mathrm{P}_{2}$ condition with $75 \%$ soil $-25 \%$ $\mathrm{OB}$ and in $\mathrm{P}_{5}$ condition with $100 \%$ OB dump respectively. An interesting observation was made in respect to the protein contain of the plants was that the protein content of the plants in $\mathrm{P}_{2}$ condition $(75 \%$ soil $-25 \% \mathrm{OB})$ was higher than the plants grown on control condition (100\% soil). Plants on $\mathrm{P}_{2}$ condition have increased their protein content in second year $(0.9 \mathrm{gm} / 100 \mathrm{gm})$ and this is true for the $\mathrm{P}_{5}$ condition $(0.2 \mathrm{gm} / 100 \mathrm{gm}$.). In rest of the study plots protein content was decreased in the second year. This result clearly indicated that protein 
content of $P$. tetragonolobus increased up to some extent with the soil-OB dump mixture $(75 \%$ soil- $25 \%$ OB dump) condition but it was decreased when percentage of OB dump was further increased. But this result needs some further investigation because mines of different coal field's area possess OB dump with different organic and inorganic components (Fig.3). Protein and carbohydrate content of the winged bean has been done by Amoo et al. (2006) in control soil condition on Nigerian variety and reported high percentage of protein and carbohydrate content than the Indian variety. They reported $33.83 \%$ crude protein and $22.30 \%$ carbohydrate content present into the seeds of Nigerian variety of winged bean in control soil condition.

All the data of biochemical results of $P$. tetragonolobus (Winged bean) were tested for its significance by applying students ' $t$ '- test (Table 1). But keeping in view of the large reclamation programme this value was least or under limit. In case of chlorophyll and carbohydrate content of the plant grown on various soil -mines spoil combination showed that winged bean could maintain their chlorophyll and carbohydrate content up to the $50 \%$ soil and $50 \%$ OB dump condition $\left(\mathrm{P}_{3}\right)$ but after that the value was decreased significantly in $\mathrm{P}_{4}$ and $\mathrm{P}_{5}$ condition. The value of chlorophyll content in $\mathrm{P}_{4}$ and $\mathrm{P}_{5}$ condition was $7.72 \mathrm{mg} / 100 \mathrm{gm}$ and $7.47 \mathrm{mg} / 100 \mathrm{gm}$ respectively and are significant at the probability level of $\mathrm{p}<0.01$ and the value of carbohydrate content in $\mathrm{P}_{4}$ and $\mathrm{P}_{5}$ condition was $3.43 \mathrm{gm} / 100 \mathrm{gm}$ and $3.16 \mathrm{gm} / 100 \mathrm{gm}$ respectively and are significant at the probability level of $p<0.001$. It means this plant can be successfully introduced for restoration process where mines spoil and normal soil composition is near about in the ratio of $1: 1$.

During the present studies, significant reductions of various biochemical parameters of winged bean were noticed in various soil and OB dump mixture condition. So their propagation on degraded land was found to be feasible both ecologically and economically. The observed decrease of growth parameters resembles the findings of Anjali and Choudhary (2012) who have studied reclamation of coalmine degraded land of Jharia by three species of Jatropha (which is a potential source of bio-diesel) and obtained germination result of these species of Jatropha which was adequate up to $75 \%$ OB dump condition. Mishra (1998), Gupta et al (2004), Kaushik et al (2005) have worked on various unexploited and underexploited plants species like Amaranthus, Chenopodium, Psophocurpus etc. on various coal mine area of Jharkhand and also found growth performance of these plant was satisfactory up to $50 \%$ soil and $50 \%$ $\mathrm{OB}$ condition. Some of these varieties have given highly promising growth rate up to the $75 \%$ OB dump condition and can be successfully used for revegetation. Similar to the present findings Gupta et al (2002) has also examined potentiality of winged bean on low nutrient land condition and observed promising results. Studies on growth performance of various morphological parameters of winged bean in various soil-OB dump composition of Raniganj and Barjora coal mine area have earlier been made by Sinha $(2012,2013)$ and reported similar results.

But keeping in mind the primary objectives of the reclamation process, slight retardation in biochemical parameters is acceptable. On the basis of overall performances, the present study clearly indicated that $P$. tetragonolobus (Winged bean) can be a promising crop plant to be used for restoration of coalfield areas. Plants grown on mine spoils exhibited a marked decrease in various biochemical parameters, but it was improved when control soil was mixed with OB dump.

\section{Conclusion}

It was concluded that large scale mining activity destroyed the natural topography of the area as well as occupying valuable and cultivable land and it causes soil loss, water and air pollution. Thus speedy rehabilitation of $\mathrm{OB}$ dumps to an acceptable post-mining land use has imperatively become an environmental necessity for sustainable development and preservation of our environment. However restoration of damaged ecology of in and around the mine spoils sites is a challenging task. In this context depending on the stabilization of waste dump slope, selection of appropriate plant species and production of plant biomass are essentially required. Because of such problems top most priority should be given to the plant selection which is important ecologically as well as economically because successful restoration programme entirely depends upon the involvement of the local people. Further, 'Winged bean', an economically important unexploited plant, has a potential for the degraded land and can be successfully introduced for the land reclamation programme.

\section{ACKNOWLEDGEMENTS}

The author is thankful to University Grant Commission (UGC), Eastern Regional Office, Kolkata, for funding this Project work. I am indebted to the Director, National Bureau of Plant Genetic Resources (NBPGR) Pusa Campus, New Delhi-110 012 for supply of good quality seeds of winged bean genotypes used in this study.

\section{REFERENCES}

Amoo, I.A., Adebayo, O.T. and Oyeleye, A.O. (2006). Chemical evaluation of Winged bean (Psophocarpus tetragonologus), Pitanga cherries (Eugenia uniflora) and Orchid fruit (Orchid fruit hyristica). AJFAND, 6 (2):1-12.

Adeyeye, E.I. (1995). Studies on the chemical composition and functional properties of african yam bean (Sphenostylis sternocarpa) flour. Ph.D thesis of Federal University of Technology, Akura, Nigeria.

Anjali and Choudhary, S.B. (2012). Germination of different Jatropha species on mine spoils of Jharia coalfield. 
Columban J. Life Sc., 13(1\&2):106-108.

Aletor, V.A. and Aladetimin, O.O. (1989). Proximate composition of some under utilized Nigeria legums. Die Nahrung, 33:999-1007.

Arnon, D.I. (1949). Copper enzyme polyphenoloxides in isolated chloroplast in Beta vulgaris. Plant physiology, 24: $1-15$.

Chaoji, V. (2002). Environmental challenges and the future of Indian coal; J. Mines, Metals and Fuels, 11: 257-262.

Cherfas, J. (1992). Trees help nature reclaim the slag heaps. New Sci., 14(15):24-29.

Cunnigham, S. D. and Berti, W. R. (1993). The remediation of contaminated soils with green plants: An overview; In: Vitro Cell. Deve. Biol., J. Tissue Cult. Assoc., 29: 207-212.

Deka Boruah, H. P., Rabha, B. K., Pathak, N. and Gogoi, J. (2008). Non-uniform patchy stomatal closure of a plant is a strong determinant of plant growth under stressful situation. Curr. Sci., 94: 1310-1314.

Dobson, A.P., Bradshaw, A.D., and Baker, A.J.M. (1997). Hopes for the future: Restoration Ecology and Conservation Biology. Science, 277:515.

Garcia, V.V. and Palmar, O. (1980). Proximate analysis of five varieties of Winged beans. J. Of Food Technology, 15: 469-476.

Gupta, K.C., Sing, R.S. and Mishra, P.K. (2002). Winged bean an under exploited but potential crop for Jharkhand region. Proc. of National seminar on "The implication of latest Technique for the development of Agriculture in Jharkhand". March, 23-24 Chas, Bokaro.

Ghosh, M.K. (2004). Effect of opencast mining on soil fertility. J. Sci. Indust. Res., 63: 1006-1009.

Gogoi, J., Pathak, N., Dowrah, J. and Deka Boruah, H. P. (2007). In situ selection of tree species in environmental restoration of opencast coalmine wasteland. Proceedings of Int. Sem. on MPT 2007, Allied Publisher, pp 678-681.

Gonzalez, R.C. and Gonzalez-Chavez, M.C.A. (2006). Metal accumulation in wild plants surrounding mining wastes: Soil and sediment remediation (SSR). Environ. Poll., 144: 84-92.

Gupta, K.C., Mishra, P.K. and Sing, R.S. (2004). Performance study of Amaranthus on mine spoil . Indian J. Environ \& Ecoplan, 8(1): 143-145.

Hodge, J.E. and Hofreiter B.T. (1962). Determination of reducing sugars and carbohydrates in analysis of sugars. In: Methods in carbohydrate chemistry (Eds. by Whistler, R.L. and BeMiller, J.N.J., Academic press,
New York).

Juwarkar, A.A. and Jumbalkar, H. P. (2008). Phytoremediation of coal mine spoil dump through integrated biotechnological approach. Biores. Technol., 99: 4732 -4741 .

Kaushik, P.K., Tripathi, Y.C., and Pandey, B.K. (2005). Potential of Bamboo in Vegetative embankment. The Indian For., 131(11): 1409-1416.

Loewus, F.A. (1952). Improvement in anthrone method for determination of carbohydrate. Anal. Chem, 24:219.

Mendez, M.O. and Maier, R.M. (2008). Phytostabilization of mine tailings in arid and semiarid environments - An emerging remediation technology; Environ. Health Prospect., 116: 278-283.

Maiti, S.K. (2007). Bioremediation of coalmine overburden dumps with special emphasis in micronutrients and heavy metals accumulation in tree species; Environ. Monit. Assess. 125:111-122.

Mishra, P.K. (1998). Introduction and performance of some under exploited plant species o n mine spoil. XI NCME - Environmental status of mine area. 130-134.

Pearson, D. (1976). The chemical analysis of food. $7^{\text {th }}$ edition. Churchill Livingstone, London and New York.

Pal, B.K. (2003). Health and safety risk assessment in environmental management of mining operations. $J$. Mines, Metals and Fuels, 51(7-8):245-250.

Raju, K.S. and Hassan, M. (2003). Role of Indian Bureau of Mines in protection of environment in the minerals sector. J. Mines, Metals and Fuels, 51(6):196-200.

Singh, S.K., Singh, S.J. and Devi, N.R. (2013). The Winged bean: A vegetable crop of Amazing Potential. Annals of Horticulture, 6(1):159-160.

Sinha, A.K. (2012). Performance study of Psophocarpus tetragonolobus (Winged bean) for land reclamation in coalmine area of Raniganj, West Bengal. Columban J. Life Sci, 13(1\&2):73-75.

Sinha, A.K. (2013). Reclamation of mining degraded land by introduction of some under exploited plants in Raniganj and Barjora coal field of West Bengal, India. Plant Science Feed, 3(10):109-116.

Sumati, R.N. and Rajagopal, M.V. (1989). Fundamental of Food and Nutrition. Wiley Eastern Limited.

Tiwary, R.K. (2001). Environmental impact of coal mining on water regime and its management. Water, air and Soil Pollution, 132: 185-199.

Wong, M.H. (2003). Ecological restoration of mine degraded soils, with emphasis on metal contaminated soils. Chemosphere, 50: 775-780. 